\title{
GROWTH OF COPPER SULPHIDE CRYSTAL IN GEL AND ITS THERMAL SPECTROSCOPIC SEMICONDUCTING CHARACTERISATIONS WITH KINETIC PARAMETERS
}

\author{
${ }^{1}$ Joshi KP, Patil S.B \\ ${ }^{1}$ Department of Physics, Dr.S.D.D. Arts College and Commerce and Science College Wada \\ Dist; Palghar
}

\begin{abstract}
:
Copper sulphides crystals are grown using simple gel technique at ambient temperature. The various lattice parameters, gel aging time, gel setting time, Effect of pH observed, Different characterization like gel aging, $\mathrm{pH}$ of gel setting of gel with their analysis and Thermal behavior of grown crystal like Thermo gravimetric Analysis TGA are Discussed. The chemical analysis confirmed contents in grown crystal of copper sulphides.
\end{abstract}

Keywords: Gel method, Monoclinic, TGA .Gel, Chemical Analysis, Color

*Corresponding author E-mail address: kp_joshi70@ rediffmail.com, cell ;+919970077906

\section{INTRODUCTION}

Copper Sulphides crystals are of considerable interest, particularly for basic studies of some of their interesting physical properties. For the growth of copper sulphides crystals, it is simple bit skilled to diffuse copper chloride solution into the gel of sodium meta silicate solution and hydrogen sulphides gas doped with gel which is alredy acidified by acetic acid. It has been reported that the size of copper sulphides crystals growing in the gel did not improve even after applying nucleation control techniques like concentration programming and neutral gel methods. But copper sulphides crystal respond for $\mathrm{P}^{\mathrm{H}}$ 4.3. to 4.4 Most of the earlier works on pure copper iodate and sulphides crystals were done with an aim of increasing the size of the crystal by controlling parameters and defects of the grown crystals. With an aim of controlling nucleation and improving the size, in the recent doping gas technics, we have grown pure copper sulphides crystals using copper chloride mixed with 
acetic acid and added sulphides gas as the supernatant for solution. The grown crystals have been characterized. In the present work, an attempt has been made to characterize gel grown crystals of copper Sulphides by Thermal analysis i.e. TGA, Chemical Analysis, effect of Gel aging on $\mathrm{pH}$, Gel Setting time, Nucleation, Gel Density on setting time ,effect of concentration on Reactant and Supernatants, concentration programming using copper chloride and copper nitrate as Dopants etc.

It is also reported that sulphides are semiconductor in nature the synthesis of sulphides are complicated because of relative low vapor pressure of the Sulphur, neverth less successively more attention is being turns toward investigating sulphides of various materials (1). There is no need to explain the role of semiconductor in the development of present electronic industries and semiconductor device for e.g. Zink sulphides (ZnS) used for lenses and other optical devices lead sulphides used in infra, red sensors; cadmium sulphides (cds) which is used in photocell. Iodate, iodides and sulphides are taken it basic material copper (2).

\section{MATERIALS AND METHODS:}

A copper sulphides crystal are grown using chemical reaction method. Using this method gel of copper chloride formed and water containing $\mathrm{H}_{2} \mathrm{~S}$ gas filled with subsequent nucleation and the crystal growth of copper sulphides takes place.

\subsection{Preparation of gel:}

Initially different concentration solution of sodium Meta silicate taken for e.g. $11 \mathrm{gm}, 13 \mathrm{gm}, 15 \mathrm{gm}, 17 \mathrm{gm}, 19 \mathrm{gm}, 23 \mathrm{gm}, 25 \mathrm{gm}$ in distilled water to get $250 \mathrm{cc}$ solution. The

solution is constantly stirred and filtered. A solution of different molarities prepared by adding proper amount of copper nitrate, copper chloride, Hydrogen sulphides gas, acetic acid and sodium Meta silicate.

A gel formation of mineral or organic acid takes place with a mixing of sodium meta silicate solution. It forms process of polymerization in the mixture of solution or resultant solution (3). In the present work, various concentration of acetic acid and those of sodium meta silicate were tried for optimum condition with different concentrations of Hydrogen Sulphides gas solution. 


\subsection{Single diffusion methods:}

Copper sulphides crystals was synthesized from acetic acid and hydrogen sulphides gas ,Acid taken in the molar ratio of $1: 1$, by slow gel technique. The reactants were thoroughly dissolved in double distilled water and stirred well using a temperature controlled magnetic stirrer to yield a homogeneous mixture of the solution. Then the solution was allowed to evaporate at room temperature up to $30^{\circ} \mathrm{c}$ which is good for crystallization and aging of the gel reaction, which results in the yield of green crystalline salt by the nucleation. The seed crystals were harvested from the solution after 8 to 10 days and a suitable seed was selected. The selected seed was suspended in the freshly prepared solution. After a period of 14 days, optically transparent, defect-free crystals were obtained from the mother solution.

In actual procedure, $5 \mathrm{cc}$ of $2 \mathrm{~N}$ acetic acid was taken, to which sodium meta silicate solution of density $1.04 \mathrm{gm} / \mathrm{cc}$ was added drop wise from burette with constant stirring performed with the help of magnetic stirrer, till $\mathrm{pH}$ of the mixture reaches a value 4.4. A 5cc of copper chloride solution of concentration $0.4 \mathrm{M}$ was added with constant stirring in mixture of acetic acid and sodium Meta silicate solution. The $\mathrm{pH}$ of the mixture was maintained at 4.4 Number of attempts were tried for optimum condition for appropriate range of $\mathrm{pH}$ values and allowed gel to obtain crystals of copper sulphides.

Table 1: Optimum lattice parameters:

\begin{tabular}{|l|l|l|}
\hline $\begin{array}{l}\text { Sr. } \\
\text { No. }\end{array}$ & Condition Lattice parameter & $\begin{array}{l}\text { Copper sulphides } \\
\text { concentrations }\end{array}$ \\
\hline 1 & Density of sodium Meta silicate & $1.04 \mathrm{~kg} / \mathrm{m}^{3}$ \\
\hline 2 & pH of mixture & 4.4 \\
\hline 3 & Amount of $2 \mathrm{~N}$ acetic acid & $5 \mathrm{ml}$ \\
\hline 4 & Temperature & Room temperature \\
\hline 5 & Gel setting time & $12-14$ days \\
\hline 6 & Gel aging time & $5-6$ days \\
\hline 7 & Concentration of $\mathrm{CuCl} 2$ & $1 \mathrm{M}$ \\
\hline 8 & Concentration of $\mathrm{Cu}_{2}\left(\mathrm{NO}_{3}\right)_{2}$ & $1 \mathrm{M}$ \\
\hline 9 & Period of growth & 24 days \\
\hline
\end{tabular}

\subsection{Observations:}

It is observed that the mixture of solution with $\mathrm{pH}$ value less than 4.2 required quite greater number of days, however in the $\mathrm{pH}$ range 4.2 to 4.4 there is appropriate waiting in 
gelation time. Room temperature and atmospheric effect also plays an important role on gelation, aging that is evaporation of water molecules form on surface of gel. To perform these experiment borosil glass test tubes of diameter $2.5 \mathrm{~cm}$ and height $25 \mathrm{~cm}$ was used as crystallizing vessels. This mixture was then transferred to the test tube, a mouth of test tube closed using cotton plug. which is used to avoid contamination and dust affecting from atmosphere. The gel setting time was 12 to 14days. This completely set gel was left for aging for 4days.i.e.96 hour's to120 hours. It is also observed that the aging of gel reduces the diameter of the capillaries in gel so that reaction can be controlled. $\mathrm{H}_{2} \mathrm{~S}$ gas dissolved in distilled water was used as supernatant.

$\mathrm{XCl}_{2}+\mathrm{Y}_{2} \mathrm{~S} \rightarrow \mathrm{XS}+\mathrm{Y}_{2} \mathrm{Cl}_{2}$

Table 2: Effect of gel density on setting time ( $\mathrm{pH}=4.4$, feed solution $\mathrm{H}_{2} \mathrm{~S}$ dissolved in distilled water)

\begin{tabular}{|l|c|c|c|c|l|}
\hline $\begin{array}{l}\text { Sr. } \\
\text { No. }\end{array}$ & $\begin{array}{c}\text { Acetic } \\
\text { acid } \\
\mathbf{2 N}(\mathbf{c c})\end{array}$ & $\begin{array}{c}\mathbf{C u C l} \text { 2 } \\
\text { incorporate } \\
\text { In gel 1M }\end{array}$ & $\begin{array}{c}\text { Density of } \\
\text { gel } \\
\text { (gm/cc) }\end{array}$ & $\begin{array}{c}\text { Gel Setting } \\
\text { time (days) }\end{array}$ & Observations \\
\hline 1 & 5 & 5 & 1.02 & 15 & Gel is not gel \\
\hline 2 & 5 & 5 & 1.03 & 13 & $\begin{array}{l}\text { Long time } \\
\text { required to set gel }\end{array}$ \\
\hline 3 & 5 & 5 & 1.04 & 12 & $\begin{array}{l}\text { Few crowded } \\
\text { crystals }\end{array}$ \\
\hline 4 & 5 & 5 & 1.05 & 10 & $\begin{array}{l}\text { Number of } \\
\text { crystals decreases }\end{array}$ \\
\hline 5 & 5 & 5 & 1.06 & 08 & Less transparent \\
\hline
\end{tabular}

The effect gel density and Gel setting time varies with constant acidification of $5 \mathrm{cc}$ using acetic acid. The incorporated solution of copper chloride of $1 \mathrm{~m}$ used for gelling mechanism.it is observed that as density of gel varies from 1.02 to 1.04 quite number of crystal grown re decreases but at the stage of density of gel $1.04 \mathrm{gm} / \mathrm{cc}$ few crowded crystals of copper sulphides crystals are seen. The number of grown crystals of copper sulphides decreases with gel setting time of 10 days. The number of grown crystals increases from decreasing gel density 1.07 to $1.05 \mathrm{gm} / \mathrm{cc}$. The crystals which were grown in test tube are transparent. The gel setting time from 7 days to 15 days which matters on crystal growth of copper hydrogen sulphides. 


\subsection{Effect of gel aging:}

Gel aging plays an effective role on the growth of copper sulphides crystals .To investigate the effect of aging on gels(4-5), gel of same $\mathrm{pH}$ and density were allowed to age for various periods before adding the feed solution over a set gel containing copper chloride. Supernatant of constant molarity was then added as a feed solution over the set gel. It was found that number of copper sulphides crystal decreases with increase in aging of gel. Aging of gel decreases the pore size as well as diffusion and nucleation density.

More aging causes more amount of water evaporation out of the gel. The effect of water evaporation should be considered before and after the formation of gel framework. Before the gel is set the evaporation of water causes an increase in gel density which in turn and decrease diffusivity of reactive sulphides ions in the gel, thereby decreasing the number of nucleation sites.

Table-3. Shows the effect of aging time on number and the quality of crystal. 1-shows graph of aging in hours against the number of crystals.

In present work, aging of 120 hours was found suitable because it makes gel neither dry or brittle nor fragile. The aim of reduction in nucleation centers can also be achieved. Hence aging period of 120 hours is the optimum condition for the growth of good quality crystals.

\subsection{Effect of gel aging time}

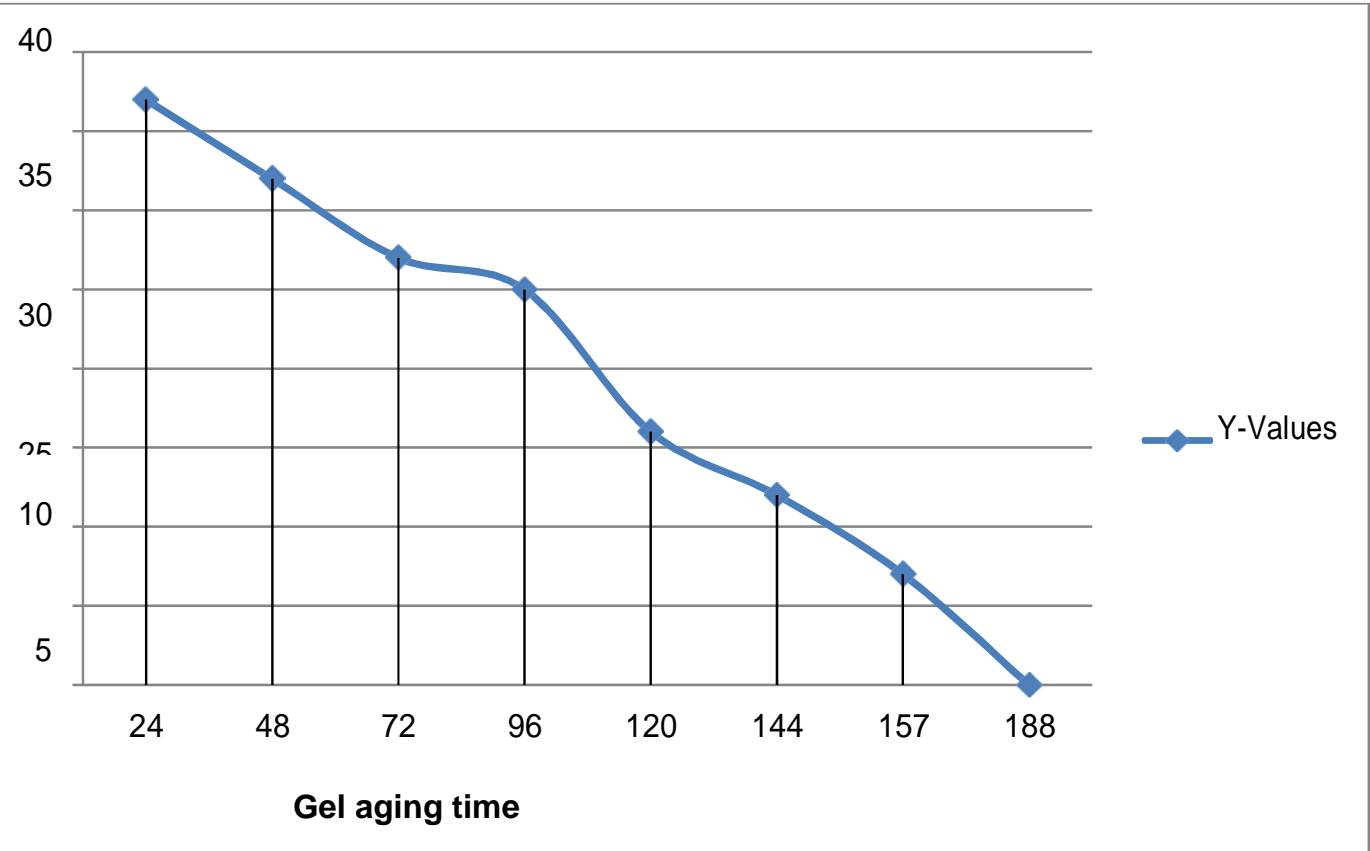

Figure 1: Plot of gel aging time against nucleation density $\mathrm{pH}=4.4$, feed solution $\mathrm{H} 2 \mathrm{~S}$ gas dissolved in distilled water 
Table: 3: Effect of gel density on number of nucleation $\mathrm{pH}=4.4$ and $1 \mathrm{M}$ of $\mathrm{CuCl}_{2}$ :

\begin{tabular}{|l|l|l|l|l|l|}
\hline $\begin{array}{l}\text { Test tube } \\
\text { no. }\end{array}$ & $\begin{array}{c}\text { Acetic acid } \\
\mathbf{2 N}(\mathbf{c c})\end{array}$ & $\begin{array}{c}\mathbf{C u C l} \\
\text { incorporated } \\
\text { In gel 1M }\end{array}$ & $\begin{array}{c}\text { Density of } \\
\text { gel }(\mathbf{g m} / \mathbf{c c})\end{array}$ & $\begin{array}{c}\text { Number of } \\
\text { nuclei formed }\end{array}$ & Observations \\
\hline 1 & 5 & 5 & 1.02 & 34 & $\begin{array}{l}\text { Small but crowded } \\
\text { crystals }\end{array}$ \\
\hline 2 & 5 & 5 & 1.03 & 29 & $\begin{array}{l}\text { Number of crystal } \\
\text { decreases }\end{array}$ \\
\hline 3 & 5 & 5 & 1.04 & 16 & $\begin{array}{l}\text { Different Shaped } \\
\text { number of crystals }\end{array}$ \\
\hline 5 & 5 & 5 & 1.05 & 14 & $\begin{array}{l}\text { translucent crystals } \\
\text { small transparent }\end{array}$ \\
\hline 5 & 5 & 5 & 1.06 & 07 & Few crystals are not \\
well defined
\end{tabular}

Table 4 : Effect of $\mathrm{pH}$ on gel Aging period =5 days, feed solution of $\mathrm{H}_{2} \mathrm{~S}$ dissolved in distilled water

\begin{tabular}{|c|c|c|c|c|c|c|}
\hline $\begin{array}{c}\text { Test } \\
\text { Tube } \\
\text { No. }\end{array}$ & $\begin{array}{c}\text { Acetic } \\
\text { acid (cc) }\end{array}$ & $\begin{array}{c}\text { CuCl2 } \\
\text { In gel } \\
\mathbf{0 . 4} \mathbf{~ M , ~ c c ~}\end{array}$ & $\begin{array}{c}\text { Sodium meta } \\
\text { silicate } \\
\mathbf{1 . 0 4} \mathbf{~ g m / c c}\end{array}$ & $\mathbf{p H}$ & $\begin{array}{c}\text { Gel setting } \\
\text { time days }\end{array}$ & Observation \\
\hline 1 & 5 & 5 & 15 & 2.0 & & Gel is not set \\
\hline 2 & 5 & 5 & 16 & 2.5 & 16 & Gel is not set \\
\hline 3 & 5 & 5 & 16.5 & 3.5 & 15 & $\begin{array}{c}\text { Whisker crystals of } \\
\text { sulphides }\end{array}$ \\
\hline 4 & 5 & 5 & 17 & 4.0 & 13 & $\begin{array}{c}\text { Small growth of } \\
\text { whisker crystals }\end{array}$ \\
\hline 5 & 5 & 5 & 18 & 4.2 & 12 & $\begin{array}{c}\text { Longer whisker } \\
\text { crystals }\end{array}$ \\
\hline 6 & 5 & 5 & 19 & 4.4 & 11 & $\begin{array}{c}\text { Crowded large } \\
\text { number crystals }\end{array}$ \\
\hline
\end{tabular}


It is observed that lower value of $\mathrm{pH}$ is quietly effect on setting of the gel as shown in table 4 . As $\mathrm{pH}$ value ranges from 2.0 to 2.5 then gel is not set and the number of days not only affect for growing crystal and setting of gel but also on the value of $\mathrm{pH}$ which acidified the solution in test tube. The time for gel setting is an important parameter for setting gel and growing crystals of copper sulphides. It is observed that the $\mathrm{pH}$ value from 3.5 pertains for growing crystals in test tube. No doubt at this stage atmospheric conditions up to higher temperature $32^{\circ} \mathrm{c}$ is suitable for growing crystals. A longer whisker crystals are seen at $\mathrm{pH}$ 4.2.but large number of crowded whisker crystals are obtained at $\mathrm{pH}$ 4.4.the figure of merit is large number of 23 copper sulphide crystals are obtained as shown in figure 2

Figure 2: Large number of Whisker crystals of copper sulphide

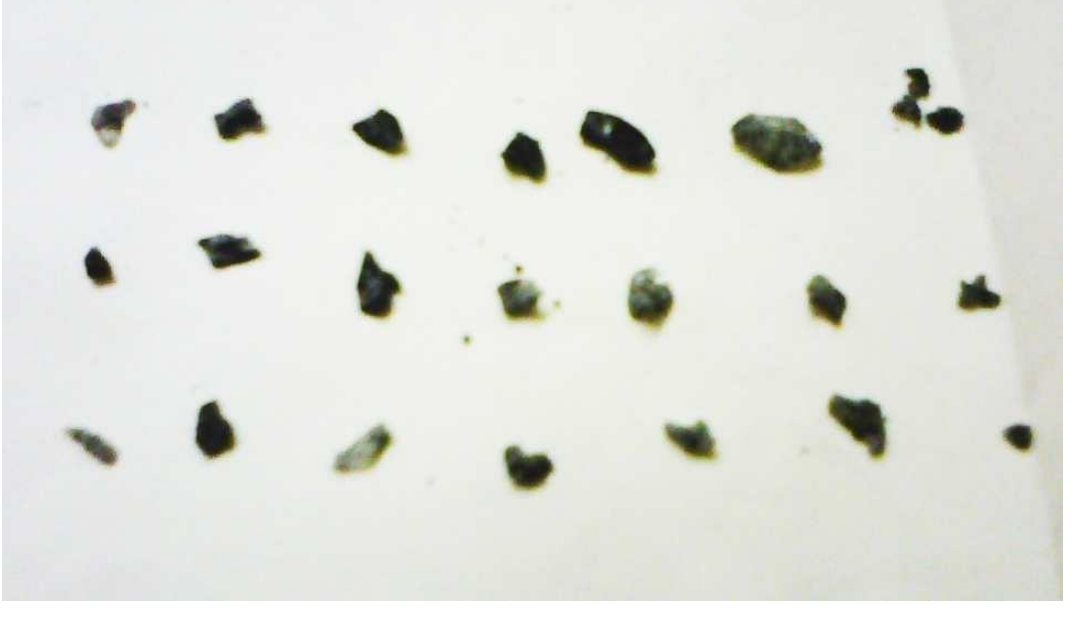

Table 5: Effect of concentration of reactant on habit, quality and size of copper sulphide crystals

\begin{tabular}{|c|c|c|c|}
\hline $\begin{array}{l}\text { Sr } \\
\text { no. }\end{array}$ & $\begin{array}{l}\text { Concentration of } \\
\text { reactant } \\
\text { in gel }\end{array}$ & $\begin{array}{l}\text { Concentration } \\
\text { of } \\
\text { reactant } \\
\text { above gel }\end{array}$ & Observation \\
\hline 1 & $\begin{array}{l}\mathrm{CuCl}_{2,}, 0.5 \mathrm{M}, \\
5 \mathrm{ml}\end{array}$ & $\begin{array}{l}\mathrm{H}_{2} \mathrm{~S} \text { dissolved } \\
\text { distilled water }\end{array}$ & $\begin{array}{l}\text { In Large number of crowded micro crystal were produced, } \\
\text { these crystal were attached to themselves form a thick } \\
\text { layer of crystal at the interface. These crystals are tinny } \\
\text { in size. }\end{array}$ \\
\hline
\end{tabular}




\begin{tabular}{|l|l|l|l|}
\hline 2 & $\begin{array}{l}\mathrm{CuCl}_{2}, 1 \mathrm{M}, \\
5 \mathrm{ml}\end{array}$ & $\begin{array}{l}\mathrm{H}_{2} \mathrm{~S} \text { dissolved } \mathrm{In} \\
\text { distilled water }\end{array}$ & $\begin{array}{l}\text { copper nulphide crystals are grown. } \\
\text { copers }\end{array}$ \\
\hline 3 & $\begin{array}{l}\mathrm{CuCl}_{2}, 1.5 \mathrm{M}, \\
5 \mathrm{ml}\end{array}$ & $\begin{array}{l}\mathrm{H}_{2} \mathrm{~S} \text { dissolved In } \\
\text { distilled water }\end{array}$ & crystals of big in size grown compared to second stage. \\
& & \\
\hline
\end{tabular}

\subsection{Effect of Concentration Programming:}

Crystal at the time of growing process, as shown in Table 3, many attempts were performed to grow good quality crystal of copper sulphides (6-8). A feed solution increases nuclei were formed. Further increase in concentration created very few nucleation centers and helps the previous nuclei to grow optimum size of copper sulphide crystal .Finally quality and transparency of copper sulphide crystal were increased due to the increase in concentration of feed solution or supernatant of hydrogen sulphide gas. In present work, solutions of hydrogen sulphide gas of same concentration were used as supernatant over a set gel containing of copper chloride. A feed solution was replaced by another dual volume in next 24 hour of the strength 0.4 M. shown in Table 3. This process was continued until the concentration of hydrogen gas reached for diffusion. It is observed that for lower concentration of feed solution, there will be no nucleation as observed

Colour: The large number of copper sulphide crystals are transparent

\subsection{Chemical analysis:}

Copper is estimated gravimetrically using dilute $\mathrm{HCl}$ by homogeneous precipitation. Accurately weighed $0.1 \mathrm{gm}$ of sample in powder form was dissolved in small quantity of double distilled water. Few drops of nitric acid were added while heating to dissolve the powder completely (9-11). Few ml of dilute sulphuric acid was slowly added with constant stirring until precipitation was obtained .it was allowed to stand for same time. Precipitate was filtered in fresh water .in a previously weighed porcelain crucible, the filter paper along with the precipitate was ignited. First it was slowly heated to dry the filter paper. The precaution should be taken that the filter paper should not catch the fire. When the filter paper was completely dried, the precipitate was strongly ignited to get ash of $\mathrm{CuSO}$. The residue was cooled. The weight of residue obtained was $0.1984 \mathrm{gm}$. 
Table 6.0 Chemical Analysis

\begin{tabular}{|l|l|l|}
\hline Ob. no. & Content of sample & Weight \\
\hline 1 & Weight of sample & $0.1 \mathrm{gm}$ \\
\hline 2 & Weight of filter paper +sample & $1.1472 \mathrm{gm}$ \\
\hline 3 & Weight of filter paper & $1.05 \mathrm{gm}$ \\
\hline 4 & Weight of the residue & $0.1984 \mathrm{gm}$ \\
\hline
\end{tabular}

Table 7: Result of chemical analysis:

\begin{tabular}{|l|l|l|}
\hline Element & \multicolumn{1}{|c|}{ Theoretical } & Practical value (\%) \\
\hline Copper & $66.51 \%$ & $65.9 \%$ \\
\hline Sulphur & $32.56 \%$ & $32.6 \%$ \\
\hline
\end{tabular}

\subsection{Thermo gravimetric Analysis (TGA):}

TGA curve of copper sulphide showed clearly two stage of decomposition. TGA curve did not show an appreciable weight change in the temperature range $0^{\circ} \mathrm{C}$ to $140^{\circ} \mathrm{C}$ Indicating that the crystals of copper sulphide are thermally stable in this range .The crystal becomes thermally unstable beyond $100^{\circ} \mathrm{C}$ The observed and calculated weight loss shown in Table 8 .

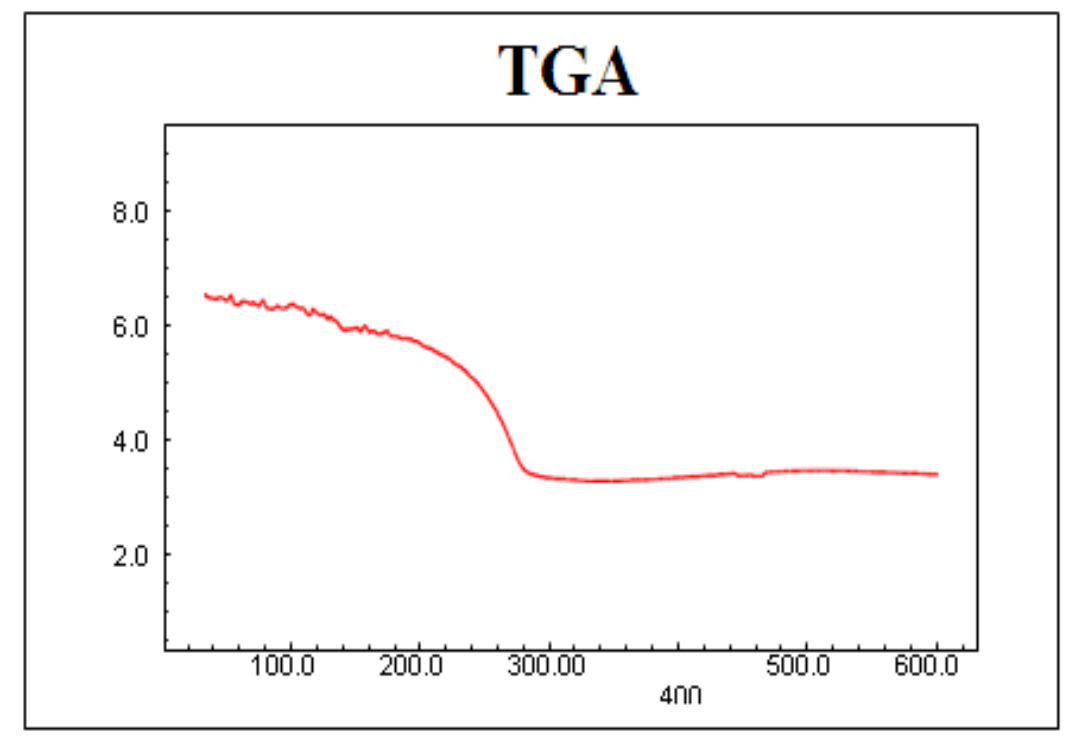

Figure 3. TGA curve of copper sulphide crystal 


\section{Reaction:}

$\mathrm{CuS}_{5} \mathrm{H}_{2} \mathrm{O}+6 \mathrm{O}_{2} \rightarrow \mathrm{H}_{2} \mathrm{O}+0.5 \mathrm{SO}_{2} \uparrow+3.2 \mathrm{SO}_{2} \uparrow+\mathrm{CuO}_{7}$

The first stage of decomposition occurs in the temperature range $142^{\circ} \mathrm{C}$ to $180^{\circ} \mathrm{C}$, in which weight loss of $11.5 \%$ agrees very well with the calculated weight loss of $11.54 \%$.This weight loss is attributed to loss of $\mathrm{H}_{2} \mathrm{O}+0.5 \mathrm{SO}_{2}$ and continuous decomposition of crystal occur. The second stage of decomposition occurs in the temperature range $220.03{ }^{\circ} \mathrm{C}$ to $310{ }^{\circ} \mathrm{C}$ In which observed weight loss of $47.15 \%$ agrees very well with the calculated weight loss of $47.23 \%$. This weight is attributed to loss of $3.2 \mathrm{SO}_{2}$ and continuous decomposition of crystal occurs. The observed trend above $600{ }^{0} \mathrm{C}$ suggest that the product formed is continuously getting decomposed. It may attribute to the formation of copper oxide of $40.48 \%$.

Table 8: TGA data of copper sulphide.

\begin{tabular}{|l|l|l|l|l|}
\hline Stage & $\begin{array}{l}\text { Temperature } \\
\text { range (0 C) }\end{array}$ & $\begin{array}{l}\text { Observed } \\
\text { weight loss } \\
\%\end{array}$ & $\begin{array}{l}\text { Calculated } \\
\text { weight } \\
\text { loss \% }\end{array}$ & $\begin{array}{l}\text { Probable loss of water } \\
\text { Molecules }\end{array}$ \\
\hline 1 & $142^{\circ} \mathrm{C}$ to $180^{\circ} \mathrm{C}$ & $11.5 \%$ & $11.54 \%$ & $\mathrm{H}_{2} \mathrm{O}+0.5 \mathrm{SO}_{2}$ \\
\hline 2 & $\begin{array}{l}220.03^{\circ} \mathrm{C} \text { to } \\
310^{\circ} \mathrm{C}\end{array}$ & $47.15 \%$ & 47.23 & $\%$ \\
\hline 3 & Residue $\mathrm{CuO}_{7}$ & $41.5 \%$ & $40.48 \%$ & $3.2 \mathrm{SO}_{2} \uparrow$ \\
\hline
\end{tabular}

\section{Conclusion:}

1) The crystal of copper sulphide can be grown by using gel technique Single diffusion gel growth technique is suitable copper sulphide crystals.

2) Different habits of copper sulphide crystals can be obtained by changing different parameters in crystal growth.

3) Chemical composition of the grown crystal by chemical analysis and EDAX match with the theoretical calculation from molecular formula.

4) Unit cell parameter value and d values match very with the reported ones 
5) The structure of copper sulphide is monoclinic confirmed by X-ray diffraction.

6) FT-IR analysis confirms the presence of fundamental infra-red frequencies, generally observed in all sulphide compounds.

7) TGA and DSC analysis confirms the presence of copper in the grown crystals.

\section{References}

[1] Joshi MS and Trivedi SG 1981 Growth of single crystals of barium iodate and strontium iodate in silica gels. Cryst. Res. Technol. 16(1) 19-26

[2] Garud SL, Mahajan NK and Saraf KB 2009 Study of gel grown mixed crystals of BaxCa (1x)(IO3)4. Bull. Mater. Sci. 32(2) 187-92

[3] Garud SL and Saraf KB 2008 Growth and study of mixed crystals of Ca Cd iodate. Bull. Mater. Sci. 31(4) 639-43

[4] Morosin B, Bergman JG and Crane GR 1973 Crystal structure, linear and nonlinear optical properties of Ca(IO3)2.6H2O. Acta. Crysta. B29 1067-72

[5] De Kock and AJR 1980 Handbook on Semiconductors vol3, edKellar SP and Moss TS (Amsterdam: North Holland) p 247

[6] Nyrit J 1982 Industrial Crystallization (Amsterdam: Elsevier) p 203

[7] Nassau K, Shiever JW and Prescot BE 1973 Transition metal iodates. I. Preparation and characterization of the $3 d$ iodates. J. Solid State Chem. 7 186-204

[8] Dasent WE and Waddington TC 1960 Iodine Oxygen Compounds. Part I. Infrared Spectra and Structure of Iodates J. Chem. Soc. 2429-32

[9] Nyquist RA and Kagal RD 1971 Infrared Spectra of Inorganic Compounds (New York: Academic Press)

[10] Rocchiccioli, C. Compt. Rend. 250 (1960) 1232.

[11] Sanyal GS and Nag K 1977 Thermal studies on the dimesoperiodates and iodates of Ca (II), Sr (II) and Ba (II) preparation and characterization of hexavalent iodates. J. Inorg. Chem. 39 1127-30

[12] Chemla DS and Zyss J 1987 Nonlinear Optical Properties of Organic Molecules and Crystals (New York: AcademicPress)

[13] Kurtz SK and Perry TT 1968A powder technique for the evaluation of nonlinear optical materials. J. Appl. Phys. 39(8) 3798-813 
[14] Bloembergen N, Armstrong JA, Ducuing J and Pershan PS 1962 Interactions between light waves in a nonlinear dielectric. Phys. Rev. Lett. 127 1918-39

[15] Franken PA, Hill AE, Peters CW and Wernreich G 1961 Generation of Optical Harmonics Phys. Rev. Lett. 7 118-9 ScieTech 2013 IOP PublishingJournal of Physics: Conference Series 423 (2013) 012060 doi:10.1088/1742-6596/423/1/012060 